peated procedures might be required for persistent PAVMs or recanalization, transcatheter embolization is a lung-sparing procedure and should therefore always be considered in cases of PAVM.

We thank Mr Richard Medeiros and Miles Dalby for their advice in editing the manuscript.

\section{References}

1. Puskas JD, Allen MS, Moncure AC, Wain JC Jr, Hilgenberg AD, Wright C, et al. Pulmonary arteriovenous malformations: therapeutic options [see comments]. Ann Thorac Surg. 1993;56:253-8.

2. Ference BA, Shannon TM, White RI Jr, Zawin M, Burdge CM. Life-threatening pulmonary hemorrhage with pulmonary arteriovenous malformations and hereditary hemorrhagic telangiectasia. Chest. 1994;106:1387-90.

3. Iqbal M, Rossoff LJ, Steinberg HN, Marzouk KA, Siegel DN. Pulmonary arteriovenous malformations: a clinical review. Postgrad Med J. 2000;76:390-4.

4. Andersen PE, Kjeldsen AD, Oxhoj H, Vase P, White RI Jr. Embolotherapy for pulmonary arteriovenous malformations in patients with hereditary hemorrhagic telangiectasia (Rendu-Osler-Weber syndrome). Acta Radiol. 1998;39:723-6.

5. Martinez FJ, Villanueva AG, Pickering R, Becker FS, Smith DR. Spontaneous hemothorax. Report of 6 cases and review of the literature. Medicine. 1992;71:354-68.

6. White RI Jr. Pulmonary arteriovenous malformations and hereditary hemorrhagic telangiectasia: embolotherapy using balloons and coils. Arch Intern Med. 1996;156:2627-8.
7. White RI Jr, Pollak JS. Pulmonary arteriovenous malformations: options for management. Ann Thorac Surg. 1994;57:519-21.

8. Bosher LHJ, Blake DA, Byrd BR. An analysis of the pathologic anatomy of pulmonary arteriovenous aneurysms with particular reference to the applicability of local excision. Surgery. 1959;45:91-104.

9. Wallenhaupt SL, D'Souza V. Combined radiological and surgical management of arteriovenous malformation of the lung. Ann Thorac Surg. 1988;45:213-5.

10. Temes RT, Paramsothy P, Endara SA, Wernly JA. Resection of a solitary pulmonary arteriovenous malformation by video-assisted thoracic surgery. J Thorac Cardiovasc Surg. 1998;116:878-9.

11. Remy J, Remy-Jardin M, Wattinne L, Deffontaines C. Pulmonary arteriovenous malformations: evaluation with $\mathrm{CT}$ of the chest before and after treatment [see comments]. Radiology. 1992;182:809-16.

12. Lee DW, White RI Jr, Egglin TK, Pollak JS, Fayad PB, Wirth JA, et al. Embolotherapy of large pulmonary arteriovenous malformations: long-term results. Ann Thorac Surg. 1997;64:930-40.

13. Barzilai B, Waggoner AD, Spessert C, Picus D, Goodenberger D. Two-dimensional contrast echocardiography in the detection and follow-up of congenital pulmonary arteriovenous malformations. Am J Cardiol. 1991;68:1507-10.

14. Duch PM, Chandrasekaran K, Mulhern CB, Ross JJ Jr, MacMillan RM. Transesophageal echocardiographic diagnosis of pulmonary arteriovenous malformation. Role of contrast and pulsed Doppler echocardiography. Chest. 1994;105:1604-5.

15. White RI Jr. Pulmonary arteriovenous malformations: how do we diagnose them and why is it important to do so? Radiology. 1992;182: 633-5.

16. White RI Jr, Pollak JS, Wirth JA. Pulmonary arteriovenous malformations: diagnosis and transcatheter embolotherapy. J Vasc Interv Radiol. 1996;7:787-804.

\title{
Fatal air embolism during computed tomography-guided pulmonary marking with a hook-type marker
}

\author{
Shoji Sakiyama, MD, PhD, ${ }^{a}$ Kazuya Kondo, MD, PhD, ${ }^{a}$ Hisashi Matsuoka, MD, ${ }^{a}$ Mitsuteru Yoshida, MD, \\ Takanori Miyoshi, MD, PhD, ${ }^{\text {a }}$ Shusaku Yoshida, MD, PhD, ${ }^{\mathrm{b}}$ and Yasumasa Monden, MD, PhD, ${ }^{\text {a }}$ Tokushima, Japan
}

$\mathrm{P}$ ulmonary marking with a hook wire, guided by computed tomography (CT), is often used to assist in the resection of small lung tumors that are difficult to identify by means of thoracoscopic surgical techniques or digital palpation. The most common complications accompanying

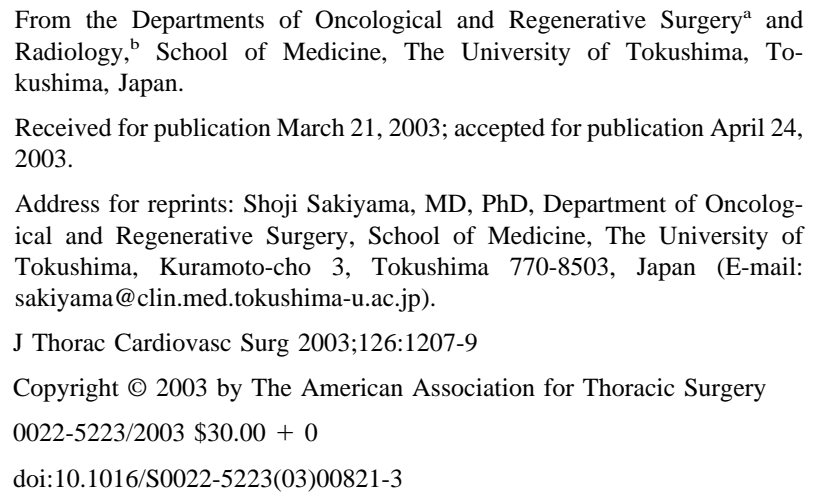

this procedure are pneumothorax, intrapulmonary hemorrhage, and hemoptysis. These complications are usually mild, self-limiting, and curable. Air embolism is a widely recognized complication of transthoracic percutaneous needle biopsy, but in the case of CTguided pulmonary marking, few complications have been reported. We report a case of fatal arterial gas embolism during hook wire localization of a pulmonary lesion. The patient mortality was mainly attributed to ischemic heart injury caused by air embolism. Physicians should be aware of this possible complication when a hook wire-type marker is used to avoid further fatalities.

\section{Clinical Summary}

A 79-year-old woman visited our hospital for an examination of a 2.0-cm abnormal shadow in the left upper lung field revealed by a mass chest radiographic survey. A chest CT demonstrated a $1.5-\mathrm{cm}$ tumor shadow with a faint density and ground-glass opacity in $S^{8}$ of the right lung in addition to a $2.0-\mathrm{cm}$ tumor in $S^{1+2}$ of the left lung (Figure 1).

The patient was known to have had pulmonary tuberculosis in her late twenties. She had no smoking history. Results of her 

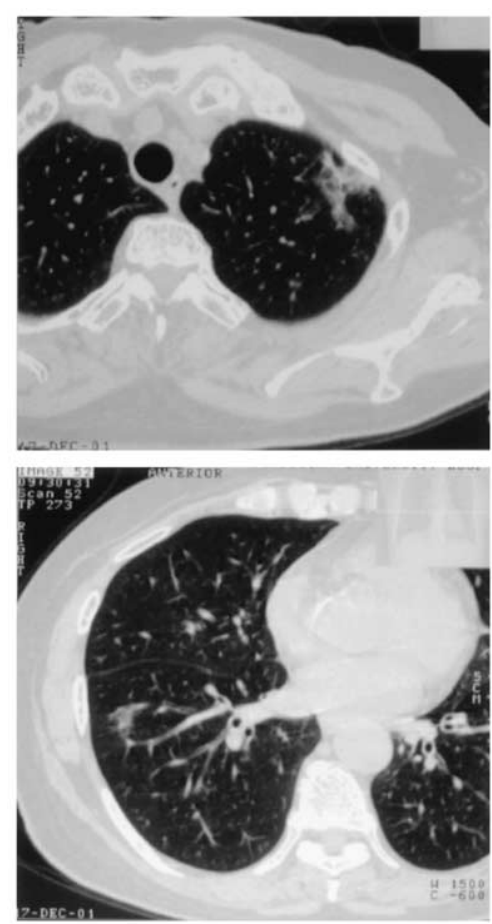

Figure 1. Thin-section CT images: Top, left lung cancer in $S^{1+2}$; bottom, faint density-type tumor with ground-glass opacity in $\mathbf{S}^{\mathbf{8}}$.

physical examination were appropriate for her age. Complete blood count, liver function, renal function, and urinalysis showed no abnormality. Pulmonary function tests revealed a vital capacity (VC) of $2.04 \mathrm{~L}$, a percent $\mathrm{VC}$ of $78.9 \%$, a forced expiratory volume in 1 second $\left(\mathrm{FEV}_{1}\right)$ of $1.04 \mathrm{~L}$, and a ratio of $\mathrm{FEV}_{1}$ to forced vital capacity (FVC) of $65.8 \%$. A CT-guided transthoracic needle biopsy was performed for the left-sided tumor, which was identified as a well-differentiated adenocarcinoma. The shadow of the right lung also indicated lung cancer. Simultaneous pulmonary wedge resections by video-assisted thoracoscopic surgery for both lesions were scheduled.

On the day of the operation, CT-guided marking for the right pulmonary tumor was performed before the patient was sent to the operating room. The procedure was performed in the left-sided semilateral position with a hook-type marking needle (Guiding Marker System; Hakko Medical Co, Nagano, Japan).

The patient was stable during the procedure. However, she had sudden cardiovascular collapse with unconsciousness, bradycardia, and hypotension as soon as she was returned to the supine position from the left-sided semilateral position after the procedure. Electrocardiography showed a remarkable ST-segment increase in leads II, III, $\mathrm{aV}_{\mathrm{F}}$, and $\mathrm{V}_{1-3}$. One hundred percent oxygen was administered with a facemask. A hypertensor was administered, and spontaneous breathing was maintained. Chest CT scanning was performed promptly. The CT scan showed an air-fluid level in the ascending aorta and air density in the right coronary artery (Figure 2).

After the air embolism was confirmed, the patient was transferred immediately to the intensive care unit (ICU). Although she
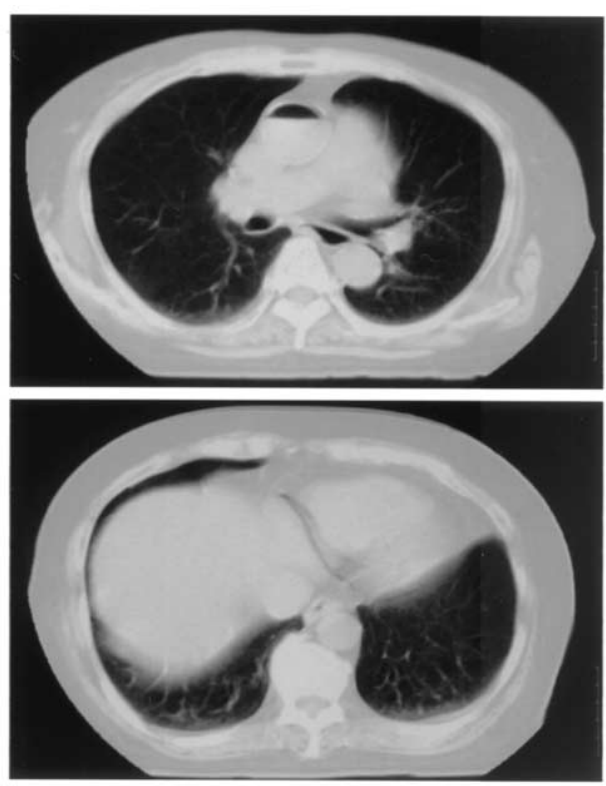

Figure 2. Chest CT scan showing air density in ascending aorta and right coronary artery.

temporarily regained consciousness after the accommodation in the ICU, she died of myocardial infarction caused by air embolism 22 hours after admission to the ICU. Although a small amount of hemoptysis was observed in the early period of the course, chest radiography showed no infiltration and pneumothorax. The hook wire was identified on the film. Pathologic autopsy was not performed.

\section{Discussion}

Gas embolism is a largely iatrogenic clinical problem that can result in serious morbidity and death. ${ }^{1}$ Most reported cases of arterial gas embolism in relation to a lung procedure occur during percutaneous lung biopsy. ${ }^{2}$ A reported case such as ours is rare. Recently, opportunities of locating small lesions in the lung and of performing video-assisted thoracoscopic surgery procedures have increased. Accordingly, some preoperative marking for small lesions are considered. Horan and colleagues ${ }^{3}$ reported a case of arterial air embolism during hook wire localization for a pulmonary nodule. The structure of the hook wire used in that case was similar to the one used on our patient. Both hook apparatuses open into a $\mathrm{V}$ shape with spring force after releasing from an introducer (a covering needle).

The possible mechanisms for air embolism during lung procedures are (1) communication between the bronchus, bronchiole, or air space and pulmonary vein and (2) communication between the pulmonary vein and the atmosphere. The first reason listed above is the most likely explanation for the outcome in our case. Although increase of airway pressure caused by a cough, the Valsalva maneuver, or positive pressure ventilation increases the risk, ${ }^{4}$ such circumstances were not found in our case. The second explanation seems less likely to apply to our case because it is doubtful that a large volume of air was sucked into the pulmonary vein through the needle. We measured the relationship between pressure gradient and airflow through the needle that we used. 
TABLE 1. Air embolism complicating CT-guided pulmonary marking

\begin{tabular}{|c|c|c|c|c|c|c|c|c|}
\hline Author (y) & $\begin{array}{c}\text { Age }(y) \\
\text { sex }\end{array}$ & Location & $\begin{array}{l}\text { Tumor } \\
\text { size }\end{array}$ & Marker & Position & $\begin{array}{l}\text { Ventilation in } \\
\text { the procedure }\end{array}$ & Documentation* & Outcome \\
\hline Our case & $79, F$ & $S^{8}$ (right) & $15 \mathrm{~mm}$ & $\begin{array}{l}21 \mathrm{G}, \text { hook } \\
\text { type }\end{array}$ & Left semilateral & Spontaneous & $\begin{array}{l}\text { Chest CT } \\
\text { (ascAo, CA) }\end{array}$ & Dead \\
\hline Satake $(2002)^{7}$ & $56, F$ & $S^{9}$ (right) & $15 \mathrm{~mm}$ & $\begin{array}{l}21 \mathrm{G} \text {, hook } \\
\text { type }\end{array}$ & Prone & Spontaneous & $\begin{array}{l}\text { Chest CT (LV, } \\
\text { descAo }\end{array}$ & Alive \\
\hline Horan $(2002)^{3}$ & $32, \mathrm{M}$ & $\begin{array}{l}\text { Lower lobe } \\
\text { (left) }\end{array}$ & $\begin{array}{l}10 \mathrm{~mm}, \\
10 \mathrm{~mm}\end{array}$ & $\begin{array}{l}20 \mathrm{G} \text {, hook } \\
\text { type }\end{array}$ & Right lateral & $\begin{array}{l}\text { Positive airway } \\
\text { pressure }\end{array}$ & $\begin{array}{l}\text { Chest CT } \\
\text { (descAo) }\end{array}$ & Alive \\
\hline $\begin{array}{l}\text { Kamiyoshihara } \\
\quad(2002)^{8}\end{array}$ & $24, F$ & $S^{8}$ (right) & $4 \mathrm{~mm}$ & $\begin{array}{l}22 \mathrm{G} \text {, hook } \\
\text { type }\end{array}$ & Left lateral & Spontaneous & $-\dagger$ & Alive \\
\hline
\end{tabular}

$A s c A o$, Ascending aorta; $C A$, coronary artery; $L V$, left ventricle; descAo, descending aorta.

*Documentation: The sites where air was detected by CT.

†A chest $\mathrm{CT}$ indicated pneumothorax of the right lung.

Under 6,11 , and $19 \mathrm{~cm} \mathrm{H}_{2} \mathrm{O}$ of pressure gradient between the needle tip and its tail, $0,0.14$, and $0.39 \mathrm{~mL} / 10$ seconds of air passed through the needle, respectively.

Horan and colleagues ${ }^{3}$ described a probable mechanism of hook wire gas embolism. In that case the wire penetrated both the venule and the bronchiole, and as a result, the springing open hook wire introduced a connection between the two and caused an air embolism. In contrast to their case, in which the marking procedure was performed during positive pressure ventilation, our case was performed during spontaneous breathing. We could not find the cause of the increase in airway pressure. The lesion was located in the periphery of the right lower lobe and became the highest position in the chest under the left-sided semilateral position. Hence, the pulmonary vein blood pressure around where the hook wire was placed might become lower than the pressure of the airway. This situation might facilitate airflow into the pulmonary vein.

The mortality and morbidity associated with transthoracic needle biopsy cannot be precisely determined but has been estimated at $0.02 \%{ }^{5}$ and $0.07 \%,{ }^{6}$ respectively. Recently, the use of CTguided pulmonary marking for small pulmonary lesions before video-assisted thoracoscopic surgery became more frequently used. Three cases of air embolism caused by CT-guided pulmonary marking were reported (Table 1). ${ }^{3,7,8}$ A hook-type marker was used in all cases. In 4 cases the lesions were present in the lower lobe of the lung. The positions in marking procedure of the 4 cases were the lateral or prone position.
We have reported a case of fatal arterial gas embolism caused by marking with a hook wire for a pulmonary lesion. Because pulmonary marking will be used more frequently in the future, the risk of the hook wire should be reevaluated.

\section{References}

1. Murphy BP, Harford FJ, Cramer FS. Cerebral air embolism resulting from invasive medical procedures. Treatment with hyperbaric oxygen. Ann Surg. 1985;201:242-5.

2. Wong RS, Ketai L, Temes RT, Follis FM, Ashby R. Air embolus complicating transthoracic percutaneous needle biopsy. Ann Thorac Surg. 1995;59:1010-1.

3. Horan TA, Pinheiro PM, Araujo LM, Santiago FF, Rodrigues MR. Massive gas embolism during pulmonary nodule hook wire localization. Ann Thorac Surg. 2002;73:1647-9.

4. Lalli AF, McCormack LJ, Zelch M, Reich NE, Belovich D. Aspiration biopsies of chest lesions. Radiology. 1978;127:35-40.

5. Greene RE. Transthoracic needle aspiration biopsy. In: Athanasoulis CA, Pfister RC, Greene RE, Robertson GH, editors. Interventional radiology. Philadelphia: WB Saunders; 1982. p. 587-634.

6. Tolly TL, Feldmeier JE, Czarnecki D. Air embolism complicating percutaneous lung biopsy. AJR Am J Roentgenol. 1988;150:555-6.

7. Satake A, Kasugai T, Mizuno K, Saito Y, Urakami T. Japanese abstract. Jpn J Chest Surg. 2002;16:390.

8. Kamiyoshihara M, Sakata K, Ishikawa S, Morishita Y. Cerebral arterial air embolism following CT-guided lung needle marking. Report of a case. J Cardiovasc Surg (Torino). 2001;42:699-700. 